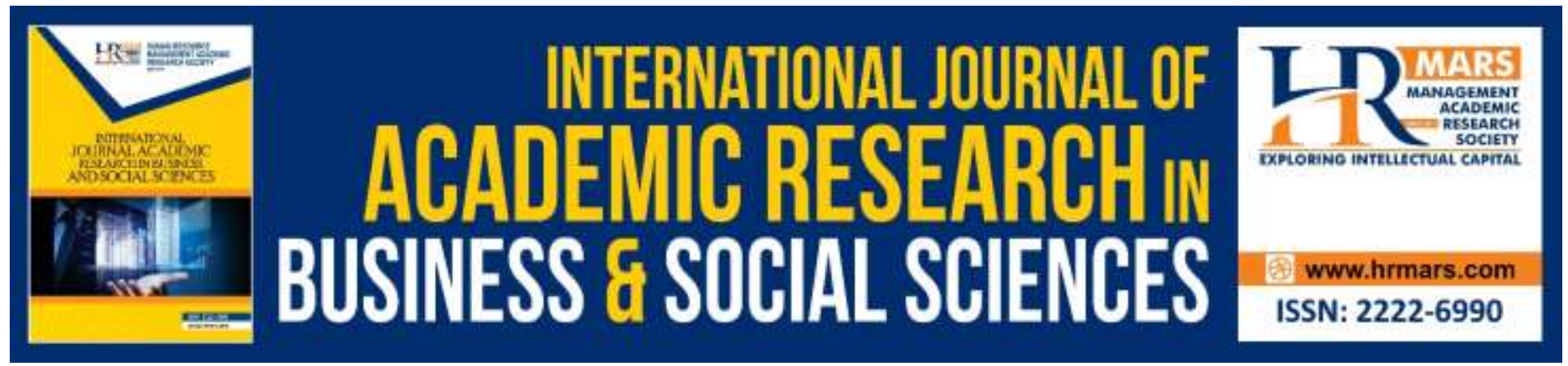

\title{
Breastfeeding of Unmarried Women through Synthetic Hormone Injection from Islamic Perspective
}

\section{Siti Fatimah Salleh, Abdullah Mustafa Theeb Fawwaz}

To Link this Article: http://dx.doi.org/10.6007/IJARBSS/v9-i11/6602

DOI: 10.6007/IJARBSS/v9-i11/6602

Received: 09 October 2019, Revised: 29 October 2019, Accepted: 07 November 2019

Published Online: 17 November 2019

In-Text Citation: (Ling et al, 2019)

To Cite this Article: Salleh, S. F., Fawwaz, A. M. T. (2019). Breastfeeding of Unmarried Women through Synthetic Hormone Injection from Islamic Perspective.International Journal of Academic Research in Business and Social Sciences, 9(11), 825-833.

Copyright: (C) 2019 The Author(s)

Published by Human Resource Management Academic Research Society (www.hrmars.com)

This article is published under the Creative Commons Attribution (CC BY 4.0) license. Anyone may reproduce, distribute, translate and create derivative works of this article (for both commercial and non-commercial purposes), subject to full attribution to the original publication and authors. The full terms of this license may be seen at: $\underline{\text { http://creativecommons.org/licences/by/4.0/legalcode }}$

$$
\text { Vol. 9, No. 11, 2019, Pg. } 825 \text { - } 833
$$

Full Terms \& Conditions of access and use can be found at http://hrmars.com/index.php/pages/detail/publication-ethics 




\title{
Breastfeeding of Unmarried Women through Synthetic Hormone Injection from Islamic Perspective
}

\author{
Siti Fatimah Salleh \\ Faculty of Islamic Contemporary Studies, Universiti Sultan Zainal Abidin, Malaysia
}

\author{
Abdullah Mustafa Theeb Fawwaz \\ Faculty of Syariah, Mu'tah Univercity, Al-Karak, Jordan.
}

\begin{abstract}
Various ways and efforts from non-governmental organizations (NGOs), ministries or hospitals in encouraging breastfeeding. These efforts open the mind of unmarried women to take synthetic hormone injection to produce breast milk in order to get the breastfeeding status on that child. The aim of the study is to analyze the syariah view of the synthetic hormone injection method and the status of infants fed by the unmarried women. The method of writing this article is a qualitative study by reviewing and analyzing documents through library research with reference to the book of turath in fiqh, language and hadith. Structured interview method with physicians and the fiqh expert was also conducted in this research. Study found that unmarried women have the ability or chances to breastfeed their baby or adoptive infants to obtain the breastfeeding status of the baby which can resolve several Islamic rules related to worship and marriage.

Keywords: Educational Thought, Islamic Mathematics, KH. Fahmi Basya, Muslim Scholar, Holistic Education.

\section{Introduction}

Innovation in science and technology which significantly contributes towards social change (Salleh, 2012) has produced several breakthroughs in the study of breastfeeding. Synthetic injection (depoprovera) is a new found method discovered to induce lactation. Such discovery received overwhelming responses from women worldwide and especially so in Malaysia, particularly those who want to go through the adoption process or women who cannot conceive after years of marriage. The injection of synthetic hormone is considered a contemporary issue, whereby syara' (Islamic law) is also governed by ta'sil (classical fiqh foundations) in the case of
\end{abstract}


discussing this issue further. The status of milk kinship which subsequently leads to having milk siblings in the case of synthetic hormones usage must be dealt with accordingly to Islamic jurisprudence so as to safeguard Maqasid al-Shari'ah which is "hifzu al-nasl" (lineage protection). Women who do not wish to get married or single not by choice and those who are married but are unable to conceive have moved on to other options made available by new scientific discovery on inducing lactation. Such approach is an alternative in the hopes of breastfeeding another's baby into being one's mahram (unmarriageable kin). By being a mahram, according to Islamic religious decree, would ease contacts between the mother and the adopted son or the father and the adopted daughter and likewise. The use of synthetic hormone injection to induce lactation is widely spread in Malaysia, however, there are still reservations among the Middle Eastern countries and Jordan as well according to recent interviews with their religious scholars (al-Harabi, 2013; Agha, 2013; Shubeir, 2013; Al Hayek, (2018). Religious scholars in those countries mentioned that such synthetic hormones injection has not existed there.

\section{Methodology}

This study is just using document analysis as a method of data collection. According to Riyanto (1996), document analysis was conducted by collecting data from books, letters, transcripts, magazines and others. Document analysis method is used to get a clear picture on the concept of freedom of expression in Islam. Description of freedom of speech in Islam is collected using data from classic and contemporary works. Therefore, this study data collection will be done by analyzing documents such as books, journals, previous studies, working papers related to the issue of freedom of speech and demonstrations in Islam. Abubakr (2007) argues that the research should ensure that the analysis will be made to answer all the questions that were set at the beginning of the study. Therefore, results from this data collection will be analyzed using content analysis. According to Krippendorff (2013), content analysis is a research technique that is done by systematically concluded through data in the form of documents, text or symbols. Therefore, data acquisition and analysis in this study was developed based on information obtained from books, journals, research papers and so last.

\section{Discussion}

\section{Breastfeeding of Unmarried Women}

For unmarried women who have a desire to get married or not, they have an alternative to having their own babies by using a method of treatment through synthetic hormone injection for milk production purposes. The success of hormone treatment in the production of milk itself provides the opportunity for unmarried women to breastfeed the baby so that the status of the baby will change to the breastfeed baby which can resolve the fiqh issues associated with breastfeeding. In the case of unmarried women, they adopted children as their own kids. However, the status of the adopted and breastfeeding children has contradictory implications in the application of Islamic law, especially in the issue of marriage. Women are allowed to get married with other baby or their adopted children, but the situation is different for women who take hormone treatment who go through synthetic hormone injection and successfully produce milk, and then 
breastfeed their baby or adopted kids. They are strictly prohibited by Islamic law to marry to their breastfeeding infants. The justification is that there has been a relationship between the two of them in relation to the mother with the breastfeeding infants. Meanwhile the relationship as adopted child to those women has changed to breastfeeding child. It also affects other branches of the mahram because of the lineage except in a number of issues specific to it. In addition, some of the implications of Islamic jurisprudence include the restrictions on genitalia, social restrictions, contact with ablution, the use of mahram for pilgrimage and umrah, all of which are and should be guided by the criteria of Islamic jurisprudence in dealing with the descendants of the mahram due to heredity.

\section{Hormone Treatment through Depo Provera Injection}

Depo provera injection has become a new alternative for unmarried women or those women who opt to live a single life and wish to adopt a child. It is their hope that through this form of treatment, the child could be their milk-child. Depo provera shots can be taken at any governmental or private medical institutions. It is an injection of synthetic progesteron (Salleh, 2015; Salleh, Jusoh, Embong, \& Mamat, 2018).

Medical discipline in administering this injection requires the intake of combine oral contraceptive pills or in layman term is the birth-control pill anddomperidone pills- which relieves nausea and vomit - that contain synthetic estrogen andprogestrogen. The usage of domperidone pill has been banned in the USA because of its severe side effects such as causing cardiac arrest, and arrhythmia,but the execution is not comprehensive enough. There are many private clinics still prescribing it because of its efficiency in increasing lactation. Another alternative introduced to replace domperidone is the maxolon pill (metochlorpramide). However the latter does not stimulate lactation as much as the former (www.webmd.com/sex/birth-control/birth-controldepo-provera; EdraSpevack, n.d., 2013; Amanullah, 2013).

This hormone injection is administered with the purpose of copying hormones found in pregnant mothers. The pill must be taken for six to nine months and this would automatically result in menstrual cycle disruption. After going thorugh this phase, women or mothers must consume vomit relieve pills (domperidone pills) until lactation happens or continuing taking the pill for three months. However, this depends on consultation with the specialists. It must be clarified that single woman or mothers who are planning to adopt the depoprovera approach, in order to ensure its effectiveness, would have to support the approach by doing breast massages or pumping the breast for seven to eight times in a day amounting to two to three hours - until lactation is successful.

In a nutshell, triggering lactation would require going through four phases. The first phase is consuming birth-control pill and domperidone to enable the body to 'copy' the process of forming mammary gland during pregnancy. The second phase is to stop taking birth-control pill 
but continue taking domperidone to trigger lactation. The third phase is pumping milk to encourage the production and flow of breastmilk and the fourth phase is to breastfeed the baby directly from the breast to increase stimulation onto the breast in order to encourage higher production of milk (Amanullah, 2013).

Induce lactation process for unmarried woman or wife who is still not able to have her own baby from her marriage is not an easy thing because they are never being pregnant or giving birth. This is because the formation and maturity of the mammary glands that happened during the pregnancy proses does not happen to these women.

During pregnancy, female body increases the production of the progesterone and estrogen hormones (produced by the ovaries) and the prolactin hormone (produced by pitituary glands) to prepare the breast for the lactation. By the end of the pregnancy, the level of progesterone and estrogen hormones will decrease while prolactin hormone will increase to start the production of maternal milk in the breast. This is the procedure that tries to be imitated by those who are never being pregnant in order to trigger the maternal milk in their breast.

In reality, single women who are willing to adopt the Depo-Provera method in order to have a milk-child which allows for permissible aurah between them, or in figh terms, to be their mahram. The concept of breastfeeding in Islam for milk-mothers is that when all conditions are fulfilled, would create lineage. Generally, lactation that happens normally has a significant tie to a husband and wife's sexual intercourse that leads to pregnancy and triggers natural lactation. According to the Hospital Pusrawi Medical Officer, $\mathrm{Dr}$ Norizan Mohd (https://www.hmetro.com.my /2017), explains that although unmarried women who take hormone treatment to produce milk, cannot produce colostrum, the production of mature milk also has the same benefits as milk produced by pregnant or giving birth mothers.

However it is different with the induce lactation approach. The breastmilk produced is solely the unmarried women own effort without any of her husband's sexual influence, same goes to single woman adopting this approach. Therefore, how far does Islamic law dictate the status of the milk-child who is being breastfeed by these unmarried women? Careful syar'i observation and evaluation must be conducted in order to dismiss any confusion related to this issue and it must be based on the views of renowned Islamic scholars in the olden days; and what is the fiqh foundation in dissecting issues relating to induce lactation. This article would give an impact to the betterment of Muslim society in which to recognize the status of a milk-child and status of the unmarried women breastfeeding other's children, subsequently providing stability and harmony within the community in the Muslim family system.

\section{Malaysian National Fatwa about Synthetic Hormone Injection and Intake for Breastfeeding} Committee of the 96th Malaysian National Committee on Islamic Religious Affairs which was held on October 13-15, 2011 discussed the Law on Breastfeeding Women. The Committee has made the following decision (http://www.e-fatwa.gov.my, October 29, 2014): 
After reviewing the evidence, arguments and views presented, Muzakarah emphasized that Islam encourages every mother to breastfeed her own baby until the baby is two years old, if they are able to do so. However, Islam also allows women who do not give birth to the babies but adopt them to breastfeed the babies themselves with the help of medical treatment.

This assertion is based on Jumhur fuqaha's view that it does not require a woman to be pregnant first to breastfeed as the Hanbali, Shafie and Hanafi states that a woman who wants to breastfeed a child is not required to have an intercourse with a man. Accordingly, the Muzakarah agrees that the use of drugs or injections to stimulate milk production is allowed as long the woman has reached puberty is either married or otherwise and that the drug or hormone used does not contain any impurities or defects. This requirement does not apply to a man who is transformed into a woman through the gender exchange.

\section{Breastfeeding Infants for Single Women According to Figh's}

In identifying fiqh foundation in this contemporary issue, it is crucial to mention the thoughts and foundations set by Islamic jurists involving breastfeeding by single or unmarried woman who experiences lactation due to hormone injection and also the status position of husband whose wife undergoes this same procedure as well. These two situations must be detailed in turath so its foundations can be applied and adapted accordingly in any upcoming issues involving breastfeeding that may appear or happen due to the advancement and innovation in science and technology.

The first situation is unmarried and single women who are able to breastfeed their baby due to synthetic hormone injection which will be detailed in fiqhiyyah foundation or ta'sil fiqhi according to the four Sunni schools of jurisprudence in order which are the school of Hanafi, Maliki, Shafi'i and Hanbali.

The general concept in milk kinship is based on what the Prophet's (pbuh) says: Meaning "The one forbidden from lineage is also forbidden from breast milk". (Ibnqudamah, 2004) Other than that, Allah s.w.t also mentioned in the holy Quran dalam surah al-Nisa' (4: 23): Translation: "Your (milk) mothers who nursed you; your sisters through nursing". The verse clearly states unlawful marriage between the milk-mother and her milkchildren.

Breastfeeding Infants for Single Women According to Fiqh's View in the School of Hanafi: In the book Bada'i'al-Sana'i'it was mentioned: Which means "unmarried women who breastfeeds, therefore milk kinship occurs for her" (Al-Kasani, 2000). In the context of this understanding, unmarried women's breastmilk produced by synthetic hormone injection would produce milk kinship relations and the child becomes her mahram in the process in accordance to the ta'silfighi Hanafi's school of jurisprudence. 
Breastfeeding Infants for Single Women According to Fiqh's View in the School of Maliki: Maliki school of jurisprudence has an opinion regarding this as shared by al-Dusuqi in his writings (alBarakat, nd): The statement gives out the meaning "that unlawful marriage still occurs even with the breastmilk of virgins or aged women who have never given birth before nor have they ever engaged in any sexual intercourse so long as what is produced is milk and not just yellowish liquid". Based on this statement by School of Maliki, it is clearly decided that breastfeeding by virgins, widows, aged women or married women but have never given birth yet produce breastmilk that is not triggered by any sexual relations, would still result in milk kinship to occur and the milk-child would be her mahram.

Breastfeeding Infants for Single Women According to Fiqh's View in the School of Shafi'i: In the discussion about unmarried women breastfeeding a child or lactation caused not by marriage, in the book al-Umm by Imam al-Shafi'l, he mentioned (Al-Shafi'I, nd): Which means: "Al-Shafi'i explains that unmarried women or widows who did not undergo marriages or other process of being pregnant and giving birth, but is able to produce breastmilk and breastfeed a child five times, will result in milk kinship so the child would be her milk-child and the child is of fatherless status".

Breastfeeding Infants for Single Women According to Fiqh's View in the School of Hanbali: In this school of jurisprudence, Ibnqudamah mentioned that women who produce breastmilk not by the means of sexual intercourse and yet breastfeed a child fulfilling all the provisions required; has two opinions. He mentioned (Ibnqudamah, 2004): An excerpt from al-Mughni mentions that "if a woman produces breastmilk without any sexual intercourse, and she breastfeeds a child, therefore the child would be her mahram in accordance with narrations that are valid and rajah (Al-Zafiri, 2002), this is also a shared opinion by Ibnhamid, Maliki, Thawri, al-Shafi'i, Abi Thawr, Hanafi and in the second narration, mahram relations does not occur...".

In the issue of unmarried women and widows who have never been pregnant and never gone through any child birth but are able to produce breastmilk and breastfeed the child while fulfilling all the required provisions, Hanbali Madh'ab has a different opinion with regards to this matter. According to the first opinion in this contemporary issue, is that women, wives, widows, or aged women who are injected with synthetic hormone in order to lactate are permissible to breastfeed a child in order to create milk kinship so marriage would be unlawful. In a second opinion, milk kinship will not occur due to the fact that lactation happens not through pregnancy (Ibnqudamah, 2004; Al-Sartawi, 2007). Therefore according to the latter, such approaches by unmarried women, widows, or wives who lactate using certain theories and breastfeed a child, the child would not be her milk-child. However, this is the least favoured opinion and less substantiated, and for that reason the first opinion is more widely accepted.

Thus, it can be clearly seen here that based on ta'sil fiqhi concepts, we are able to overcome contemporary issue that exists due to innovation in science and technology which creates 
synthetic hormone injection and antidopaminergic in breastfeeding. Constructed upon Islamic jurists close observations and analysis, it can be concluded that the status of milk kinship is established accordingly to Islamic law between a woman who breastfeeds a child with breastmilk produced through synthetic hormone injection and not by sexual intercourse between a husband and wife.

\section{Conclusion}

Studies on the fiqh views on breastfeeding of unmarried women through the production of maternal milk by providing synthetic hormone injection treatment have brought about a few findings. Amongst others are:

1. Innovations in science and technology have given rise to new discoveries in breast milk production methods which is through synthetic hormone injection treatments.

2. This treatment also produces matured maternal milk and has the same nutrition as milk of pregnant or giving birth mother.

3. Single women have a dominant opportunity to get the breastfeeding infants either by breastfeeding the baby or their own adopted children by considering the conditions of breastfeeding.

4. The hukm for a woman who is taking synthetic hormone injection to facilitate lactation is recommended if the substance in the injection are not haram and do not cause harm to the woman or her milk-child.

5. Hence, the child that feeds on the milk produced from the synthetic hormone injection would be considered her milk-child, according to the four mu'tabar schools which are Hanafi, Maliki, Shafi'i and Hanbali.

Funding: This study received no specific financial support.

Competing Interests: The authors declare that they have no competing interests.

Contributors/Acknowledgement: All authors contributed equally to the conception and design of the study. We express our deepest gratitude to Fundamental Research Grant Scheme (FRGS) Malaysia Education Ministry through Center for Research Excellence \& Incubation Management (CREIM) and Faculty of Islamic Contemporary Studies, Universiti Sultan Zainal Abidin for supporting our intellectual endeavor.

\section{References}

Agha, K. D. (Head of FiqhdanUsul Department, Jami'ah al-'Ulum al-Islamiyyah al-'Alamiyyah (WISE), Jordan), in an interview with the author, 18 April 2013.

Al Hayek, M. A. (2018). The Relationship Between Sales Revenue and Net Profit with Net Cash Flows from Operating Activities in Jordanian Industrial Joint Stock Companies, International Journal of Academic Research in Accounting, Finance and Management Sciences 8 (3): 149-162. 
Al-Barakat, S. A. D. (n.d.), al-Sharhu al-Saghir 'Ala Aqrab al-Masalik lla Mazhab al-Imam Malik, n. d: Isa al-Babi al-Halabi wa Shurakahu.

Al-Harabi, H. M. (Associate Professor Fiqh Department, Jamiah al-Islamiyah bi al-Madinah alMunawwarah, Arab Saudi), in an interview with the author in Sultan Azlan Shah Islamic University College, Perak, 12 June 2013.

Al-Kasani, 'A. A. B. M. (2000), Bada'i al-Sana'i Fi Tartib al-Shara'i. Tahqiq: Muhammad 'Adnan bin Yasin Darwish, Beyrut: Mu'assasah al-Tarikh al-'Arab.

Al-Sartawi, M. A. (2007), Syarah Qanun al-Ahwal al-Syakhsiyyah, (2007), Amman-Jordan: Dar alFikr.

Al-Syafi'i, A. A. M. I. (n.d.), al-Um, Al-Urdun: Baitul Afkar al-Dauliyyah.

Al-Zafiri, M. M. Salih. (2002), Mustalahat al-Mazahib al-Fiqhiyyah, Lubnan: Dar Ibn Hazim).

Amanullah, H. (Doctor, Medical Officer UD48, Langkawi District Health Office) in an interview with the author, 30 September 2013.http://www.e-fatwa.gov.my, 29 Oktober 2014. https://journal.unisza.edu.my/jimk/index.php/jimk/article/view/91, dilayari pada 7 Ogos 2019.

https://www.hmetro.com.my/hati/2017/09/262315/penyusuan-anak-angkat, dilayari pada 7 Ogos 2019.

Ibnqudama. (2004), al-Mughni, al-Urdun: Bayt al-Afkar al-Dawliyyah.

Salleh, M., Jusoh, A., Embong, R., \& Mamat, M. (2018). Learning Organizational Model in the 21th Century Classroom at Sultan Mahmud Science Secondary School in Terengganu, Malaysia. International Journal of Academic Research in Progressive Education and Development, $7(4), 410-426$.

Salleh, S. F. (2012) The Connection between Social Change Terminology and 'Urf in Juristic Reasoning Methodology, International Seminar On Al-Quran In Contemporary Society, 1-2 December 2012, Seminar Proceedings (SQ 2012), UniSZA.

Shubeir, U. (Professor Dr, Usul Fiqh Expert, Qawa'id Fiqh, Fiqh, University of Sharjah, UAE), in an interview with the author in Islamic Science University of Malaysia, Nilai, 24 October 2013. www.webmd.com/sex/birth-control/birth-control-depo-provera, 29 October 2014; EdraSpevack, ND “Depo-Provera”, Integrative Medicine • Vol. 12, No. 1 •(February 2013). 